\title{
KNOWLEDGE OF ASSERTIVE COMMUNICATION AMONG B.SC NURSING STUDENTS IN SELECTED NURSING COLLEGES AT JAIPUR, RAJASTHAN
}

\author{
Mr.Peekesh Kumar ${ }^{1}$ Dr. (Prof.) Yogesh Yadav
}

${ }^{1}$ Professor \& HOD Psychiatric nursing, Metro College of nursing greater noida up

${ }^{2}$ Dean \& Principal, Maharaj vinayak global University, college of nursing Dhand Jaipur

Corresponding Email: pk.pankajsinghal4u@gmail.com

\begin{abstract}
:
Introduction : Communication is an activity of conveying meaningful information; it is exchanging information in the form of messages, symbols, thoughts, signs and opinion. It is a process by which meaning is assigned and conveyed in an attempt to create shared understanding. Assertiveness is... expressing our thoughts, feelings, and beliefs in a direct, honest, and appropriate way.
\end{abstract}

Material and Method : The present study will be conducted in the St. Florence College of Nursing and Institute of medical technology and Nursing Education, Sitapura, Jaipur. In the study 300 samples were selected from the population by using simple random sampling technique. Evaluative approach and quasi experimental one group pre-test and post test design was adopted. Structured knowledge questionnaire were used to collect the data.

Results : Findings revealed that the highest $50 \%$ of the B.Sc. nursing students were in the age group of $21-23$ years, $80 \%$ of them were males, $80 \%$ were belongs to Hindu religion, $60 \%$ were belongs to nuclear family, $29 \%$ of the respondents father educated upto Graduate $\& 28 \%$ of the respondents mother educated up to senior secondary, $86 \%$ were not having previous knowledge about assertive communication and finally $42 \%$ were receiving information from their teachers. During Pre-test $86.7 \%$ of respondents have inadequate knowledge level; $13.3 \%$ of the respondents have moderate knowledge level and finally none of the respondents have adequate knowledge on Assertive Communication

Conclusion : Students have less moderate knowlege level and none of them have adequate knowledge about assertive communication.

Key words : Knowledge, Assertive communication, B.Sc Nursing Students, Nurse patient relationships.

\section{INTRODUCTION}

Communication is defined as the exchange of thoughts, ideas, feelings, information, opinions, and knowledge. It is also defined as an act by which one person gives or receives from personal information about that person's needs, desires, perceptions, knowledge or affective status.

Communication is the activity of conveying information. The word communication has been derived from the Latin word 'communis', meaning to share. It basically involves a sender, a message 
and a receiver. Communication is given, receiving or exchanging ideas, data, information, signals or messages through appropriate media, enabling individuals or groups to persuade, to seek information, to give information or to express emotions. ${ }^{3}$

Assertiveness is... expressing our thoughts, feelings, and beliefs in a direct, honest, and appropriate way. It means that we have respect both for ourselves and for others. Being assertive is not about being pushy or superior. It's about communicating what you want in a clear, level-headed manner. An assertive person effectively influences, listens, and negotiates so that others choose to cooperate willingly. Assertiveness is the ability to express one's feelings, opinions, beliefs, and needs directly, openly and honestly, while not violating the personal rights of others. Assertive staff nurses are able to present suggestions in a direct, comfortable way, give and take criticism, assess the rights and responsibilities in a nursery situation, and act on assessments in a thoughtful problemsolving way. When nurses express a lack of confidence and a lack of assertiveness, patients may notice.

\section{MATERIAL AND METHODS}

An evaluative approach was used as appropriate one for present study. The main aim of this study was to find the effectiveness of structured teaching programme on knowledge regarding assertive communication as in form of nurse patient relationship by comparing pre-test and post-test knowledge score. To associate the pre tests mean knowledge score with selected socio demographic variables of B.Sc nursing students.

\section{RESULTS}

\section{SECTION A}

\section{PERCENTAGE DISTRIBUTION OF SOCIO-DEMOGRAPHIC VARIABLES OF THE SUBJECTS}

Table 1: Frequency and percentage distribution of Respondents by Age in years

\begin{tabular}{|c|c|c|c|}
\multicolumn{5}{|c}{$\mathbf{N}=300$} \\
\hline $\begin{array}{c}\text { S } \\
\text { No }\end{array}$ & Age & Frequency & Percentage \\
\hline 1. & $18-20$ Years & 110 & $37.0 \%$ \\
\hline 2. & $21-23$ Years & 150 & $50.0 \%$ \\
\hline 3. & $24-26$ Years & 40 & $13.0 \%$ \\
\hline & Total & 300 & $100 \%$ \\
\hline
\end{tabular}

Table: 1 show that out of 300 students, 110 students $(37.0 \%)$ belong to age group of 18 20 years, 150 students $(50.0 \%)$ belong to age group of 21-23 years, and 40 students $(13.0 \%)$ belong to the age group of $24-26$ years.

\section{GFNPSS-International Journal of Multidisciplinary Research, Volume1, Issue 4, September 2020}




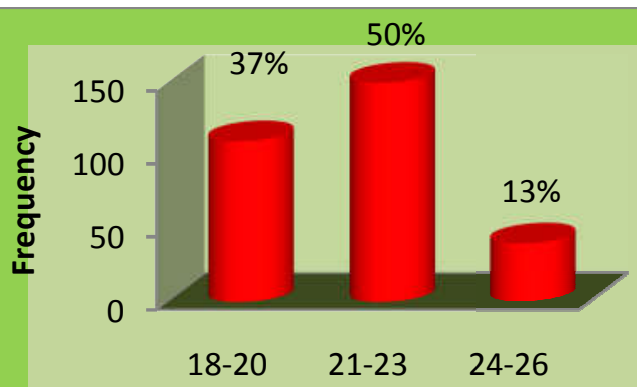

Age in Years

Figure 3: Distribution of students according to Age in years

Table 2: Frequency and percentage distribution of Respondents by Gender $\mathbf{N}=\mathbf{3 0 0}$

\begin{tabular}{|c|c|c|c|}
\hline $\begin{array}{c}\text { S } \\
\text { No }\end{array}$ & Gender & Frequency & Percentage \\
\hline 1. & Male & 240 & $80.0 \%$ \\
\hline 2. & Female & 60 & $20.0 \%$ \\
\hline \multicolumn{2}{|c|}{ Total } & 300 & $100 \%$ \\
\hline
\end{tabular}

Table: 2 show that out of 300 students, 240 students $(80.0 \%)$ belong to Male Gender, 60 students $(20.0 \%)$ belong to Female Gender.

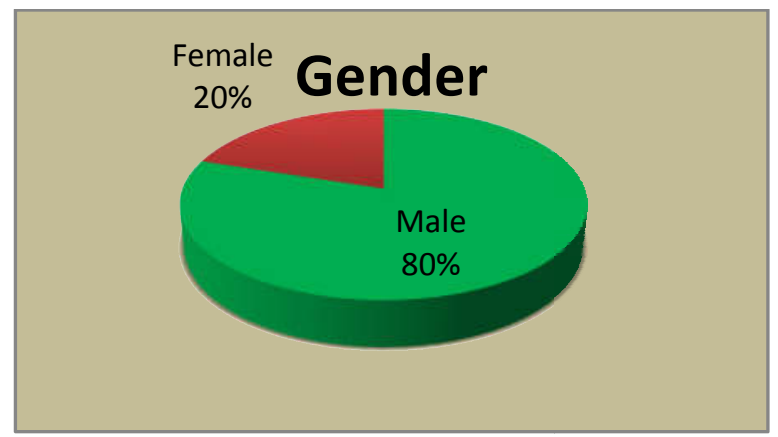

Figure 4: Distribution of students according to Gender

Table 7: Frequency and percentage distribution of Respondents by Previous knowledge about Assertive communication $\mathbf{N}=\mathbf{3 0 0}$

\begin{tabular}{|c|c|c|c|}
\hline S No & $\begin{array}{c}\text { Previous knowledge } \\
\text { about Assertive } \\
\text { communication }\end{array}$ & Frequency & Percentage \\
\hline 1. & Yes & 42 & $14.0 \%$ \\
\hline 2. & No & 258 & $86.0 \%$ \\
\hline \multicolumn{2}{|c|}{ Total } & 300 & $100 \%$ \\
\hline
\end{tabular}

Table: 7 Previous knowledge shows that out of 300 students $258(86.0 \%)$ of respondents were not having previous knowledge about assertive communication and $42(14.0 \%)$ of the respondents were having previous knowledge about assertive communication. It was inferred that majority of B.Sc Nursing students were not having previous knowledge about assertive communication.

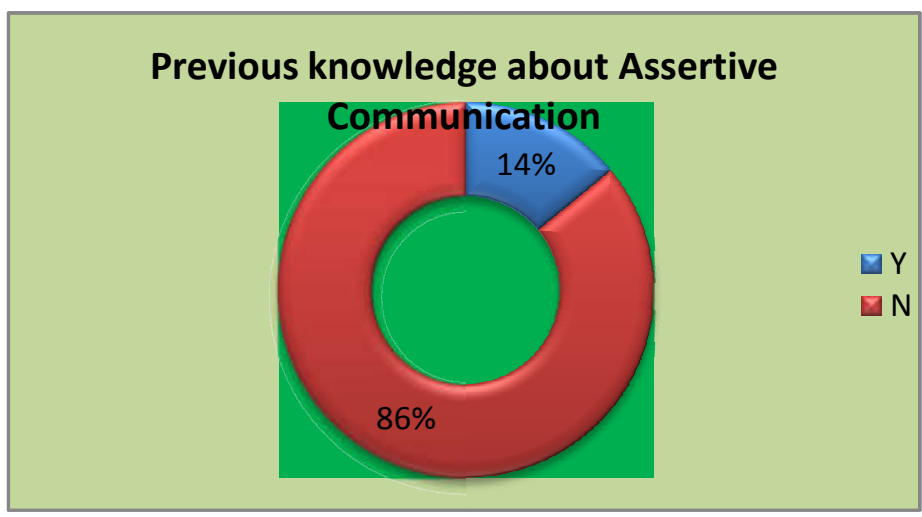


Figure 9: Distribution of students according to previous knowledge

Table 8: Frequency and percentage distribution of Respondents by source of Information

$\mathbf{N}=\mathbf{3 0 0}$

\begin{tabular}{|c|c|c|c|}
\hline S No & $\begin{array}{c}\text { Source of } \\
\text { Information }\end{array}$ & Frequency & Percentage \\
\hline 1. & Teachers & 125 & $42.0 \%$ \\
\hline 2. & Friends & 75 & $25.0 \%$ \\
\hline 3. & Relatives & 30 & $10.0 \%$ \\
\hline 4. & Mass media & 70 & $23.0 \%$ \\
\hline \multicolumn{2}{|c|}{ Total } & 300 & $100 \%$ \\
\hline
\end{tabular}

Table: 8 Source of Information shows that out of 300 students $125 \quad(42.0 \%)$ of respondents were receiving the information from their teachers; $75(25.0 \%)$ of the respondents were receiving information through their friends; $30(10.0 \%)$ of them through relatives and finally $70(23.0 \%)$ of the respondents through mass media. It was inferred that majority of B.Sc. Nursing Students were receiving information through their teachers.

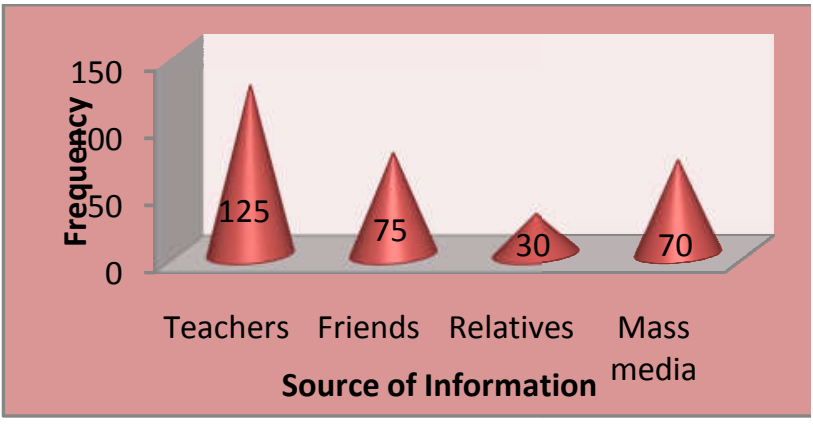

Figure 10: Distribution of students according to source of information

SECTION B

TABLE 9: Data Shows the Association between

Pre-test Knowledge Scores on Assertive

\section{Communication and Its Benefits in Nurse Patient}

Relationship and Selected Socio-Demographic

Variables.

\begin{tabular}{|c|c|c|c|c|c|c|c|c|}
\hline \multirow{3}{*}{ SN } & \multirow{3}{*}{ Variable } & \multirow{3}{*}{ Category } & \multicolumn{5}{|c|}{ Knowledge scores } & \multirow{3}{*}{$\begin{array}{c}\chi^{2} \\
\text { value } \\
\text { (p- } \\
\text { value) }\end{array}$} \\
\hline & & & \multicolumn{2}{|c|}{ Inadequate } & \multicolumn{2}{|c|}{ Moderate } & \multirow[b]{2}{*}{$\begin{array}{r}\text { Tot } \\
\text { al }\end{array}$} & \\
\hline & & & $\mathbf{f}$ & $\%$ & f & $\%$ & & \\
\hline \multirow[t]{3}{*}{1.} & \multirow{3}{*}{$\begin{array}{c}\text { Age } \\
\text { (In Years) }\end{array}$} & $18-20$ & 105 & 35.0 & 05 & 2.0 & 110 & \multirow{3}{*}{$\begin{array}{c}0.51 \\
(0.78)_{\mathrm{N}} \\
\mathrm{s}\end{array}$} \\
\hline & & $21-23$ & 142 & 47.0 & 08 & 3.0 & 150 & \\
\hline & & $24-26$ & 37 & 12.0 & 03 & 1.0 & 40 & \\
\hline \multirow[t]{2}{*}{2.} & \multirow[t]{2}{*}{ Gender } & Male & 230 & 77.0 & 10 & 3.0 & 240 & \multirow{2}{*}{$\begin{array}{c}0.08 \\
(0.78)_{\mathrm{N}} \\
\mathrm{S}\end{array}$} \\
\hline & & Female & 57 & 19.0 & 03 & 1.0 & 60 & \\
\hline \multirow[t]{4}{*}{3.} & \multirow[t]{4}{*}{ Religion } & Hindu & 232 & 77.4 & 08 & 2.67 & 240 & \multirow{4}{*}{$\begin{array}{c}4.5048 \\
(0.21)_{\mathrm{N}} \\
\mathrm{s}\end{array}$} \\
\hline & & Muslim & 33 & 11.0 & 02 & 0.67 & 35 & \\
\hline & & Christian & 18 & 6.0 & 02 & 0.67 & 20 & \\
\hline & & Sikh & 05 & 1.68 & - & - & 05 & \\
\hline \multirow[t]{2}{*}{4.} & \multirow{2}{*}{$\begin{array}{l}\text { Type of } \\
\text { Family }\end{array}$} & Nuclear & 172 & 57.4 & 08 & 2.6 & 180 & \multirow{2}{*}{$\begin{array}{c}0.23 \\
(0.63)_{\mathrm{N}} \\
\mathrm{s}\end{array}$} \\
\hline & & Joint & 116 & 38.7 & 04 & 1.3 & 120 & \\
\hline \multirow{6}{*}{5.} & \multirow{6}{*}{$\begin{array}{c}\text { Education of } \\
\text { Father }\end{array}$} & Illiterate & 17 & 5.7 & - & - & 17 & \multirow{6}{*}{$\begin{array}{c}21.21 \\
(0.06)_{\mathrm{N}} \\
\mathrm{s}\end{array}$} \\
\hline & & Primary & 20 & 6.7 & 02 & 0.6 & 22 & \\
\hline & & Secondary & 50 & 16.7 & 03 & 1.0 & 53 & \\
\hline & & $\begin{array}{c}\text { Senior } \\
\text { secondary }\end{array}$ & 69 & 23.0 & 05 & 1.6 & 74 & \\
\hline & & Graduation & 80 & 26.7 & 06 & 2.0 & 86 & \\
\hline & & $\begin{array}{c}\text { Post } \\
\text { graduation }\end{array}$ & 45 & 15.0 & 03 & 1.0 & 48 & \\
\hline \multirow{6}{*}{6.} & \multirow{6}{*}{$\begin{array}{c}\text { Education of } \\
\text { Mother }\end{array}$} & Illiterate & 22 & 7.3 & - & - & 22 & \multirow{6}{*}{$\begin{array}{c}20.09 \\
(0.049) \\
\text { NS }\end{array}$} \\
\hline & & Primary & 16 & 5.3 & 02 & 0.7 & 18 & \\
\hline & & Secondary & 76 & 25.3 & 04 & 1.3 & 80 & \\
\hline & & $\begin{array}{c}\text { Senior } \\
\text { secondary }\end{array}$ & 80 & 26.7 & 04 & 1.3 & 84 & \\
\hline & & Graduation & 52 & 17.4 & 04 & 1.3 & 56 & \\
\hline & & $\begin{array}{c}\text { Post } \\
\text { graduation }\end{array}$ & 37 & 12.4 & 03 & 1.0 & 40 & \\
\hline \multirow[t]{2}{*}{7.} & \multirow[b]{2}{*}{$\begin{array}{c}\text { Previous } \\
\text { knowledge } \\
\text { about } \\
\text { assertive } \\
\text { communicati } \\
\text { on }\end{array}$} & Yes & 40 & 13.3 & 02 & 0.7 & 42 & \multirow{2}{*}{$\begin{array}{c}17.45 \\
(0.467) \\
\text { NS }\end{array}$} \\
\hline & & No & 248 & 82.7 & 10 & 3.3 & 258 & \\
\hline 8. & Source of & Teachers & 119 & 39.7 & 06 & 2.0 & 125 & 4.24 \\
\hline & Information & Friends & 69 & 23.0 & 06 & 2.0 & 75 & $(0.29)_{\mathrm{N}}$ \\
\hline & & Relatives & 27 & 9.0 & 03 & 1.0 & 30 & s \\
\hline & & Mass media & 65 & 21.7 & 05 & 1.6 & 70 & \\
\hline
\end{tabular}




\section{SECTION C}

TABLE 10: Distribution of Overall

Respondent Knowledge Level on Assertive Communication and its Benefits in Nurse Patient Relationship in Pre-test.

$$
\mathbf{N}=\mathbf{3 0 0}
$$

\begin{tabular}{|c|c|c|c|c|c|}
\hline \multicolumn{2}{|c|}{$\begin{array}{c}\text { Inadequate } \\
\text { Knowledge } \\
(0-13)\end{array}$} & \multicolumn{2}{c|}{$\begin{array}{c}\text { Moderate } \\
\text { Knowledge } \\
(14-26)\end{array}$} & \multicolumn{2}{c|}{$\begin{array}{c}\text { Adequate } \\
\text { Knowledge } \\
(27-40)\end{array}$} \\
\hline N & $\%$ & N & $\%$ & N & $\%$ \\
\hline 260 & 86.7 & 40 & 13.3 & - & - \\
\hline
\end{tabular}

Table 10: reveals the distribution of overall respondent knowledge level regarding Assertive Communication and Its Benefits in Nurse Patient Relationship before structured teaching program.

From the above table shows that $86.7 \%$ of respondents have inadequate knowledge level; $13.3 \%$ of the respondents have moderate knowledge level and finally none of the respondents have adequate knowledge on Assertive Communication and Its Benefits in Nurse Patient Relationship before structured teaching program.

\section{DISCUSSION}

The present study was conducted to assess the effectiveness of structured teaching programme on knowledge regarding assertive communication and its benefits in nurse patient relationship among B.Sc. nursing students in selected nursing colleges at Jaipur.

In order to achieve the objectives of the study, one group pre-test and post-design with Pre-experimental design was adopted. The sample comprised of 300 B.Sc. nursing students. The data were collected from them before and after the administration of structured teaching program using a structured questionnaire.

\section{The objectives of the study}

1. To assess pre test levels of knowledge on assertive communication and its benefits in nurse patient relationship of B.Sc nursing students.

2. To assess post test levels of knowledge on assertive communication and its benefits in nurse patient relationship of B.Sc nursing students.

3. To evaluate the effectiveness of STP on assertive communication and its benefits in NPR by comparing the differences between the pre test and post test knowledge scores.

4. To associate the pre tests mean knowledge score with selected socio demographic variables of B.Sc nursing students.

\section{CONCLUSION}


This presents study concluded that implications to nursing fields, limitations, and delimitations with study designs and methods and recommendations of the study. The focus of this study was to assess the effectiveness of structured teaching programme on knowledge of assertive communication and its benefits in nurse patient relationship among B.Sc Nursing students at St. Florence college of Nursing and Institute of Medical Technology and Nursing Education, Sitapura at Jaipur.

\section{BIBLIOGRAPHY}

\section{JOURNAL}

01. Pepson VK (1997) On My Own Two Feet Educational Resource Materials for use in Substance Abuse. Education ISBN 2nd Edition Dept. of Education and Science, Ireland.

02. Fangau VK (2015) Therapeutic communication. srjis journal III/XVI: 2575-82.

03. Galata SD (2018) Assertiveness and Academic Achievement motivation of Adolescent Students in Selected Secondary Schools of Harari Peoples Regional State, Ethiopia. 6(4): 40.International Journal of Education and Literacy Studies

04. Ahmad AE et.al. (2016) The Effectiveness of Assertiveness Training on the Levels of Stress, Anxiety, and Depression of High School Students. Iran Red Crescent Med J; 18(1): 25-29.

05.Taraneh T L, Mohammad A, et.al. (2017) Assertiveness and the Factors Affecting it Among Nursing Students. International Journal of New Technology and Research: 3(5); 34-38.

06. Stolyarova, E, Fedotova, M, et.al. (2018) The survey on improving assertiveness as a soft skill in university students: 7(1); 865-70.

07. Susmita P, Simi J.L, et.al (2016) Effectiveness of Assertiveness Training on Self-Esteem among Adolescent Girls in Selected School, Nepal. International Journal of Health Sciences \& Research: 6(8); 241-246.

\section{BOOKS}

1. Sr. Nancy (2005) Textbook of principles and practices of nursing. $\mathrm{N}$ R publications, New Delhi.

2. Caur M. Text book of nursing education; $2^{\text {nd }}$ ed; $V$ publications; New Delhi.

3. Potter AP \& Perry AG (2010) Text book of fundamentals of nursing, 6th ed; Elsevier 